\title{
Revision of Hellén types of Alloxysta Förster (Hymenoptera: Figitidae, Charipinae)
}

\author{
Mar Ferrer-Suay, Jesús Selfa, María Victoria Seco \& Juli Pujade-Villar
}

Ferrer-Suay, M., Selfa, J., Seco, M. V. \& Pujade-Villar, J. 2014: Revision of Hellén types of Alloxysta Förster (Hymenoptera: Figitidae, Charipinae). Entomol. Fennica 25: 86-101.

Alloxysta type material described by Hellén and deposited in the Finnish Museum of Natural History (Helsinki, Finland), and the Göteborg Naturhistoriska Museet (Göteborg, Sweden) is revised. Nine species were studied; seven are considered valid: Alloxysta apteroidea Hellén, 1963; Alloxysta brachycera Hellén, 1963; Alloxysta glebaria Hellén, 1963; Alloxysta heptatoma Hellén, 1963; Alloxysta nigricans Hellén, 1963; Alloxysta patens Hellén, 1963 and Alloxysta soluta Hellén, 1963. These species are completely redescribed and their diagnostic characters are illustrated in corresponding plates. Alloxysta islandica Hellén, 1931 is here synonymized with Phaenoglyphis villosa (Hartig, 1841). The synonymy of Alloxysta ruthei Hellén, 1931 with Alloxysta fuscipes (Thomson, 1862) is confirmed. Lectotypes and paralectotypes have been established when necessary.

M. Ferrer-Suay \& J. Pujade-Villar, Universitat de Barcelona, Facultat de Biologia, Departament de Biologia Animal. Avda. Diagonal 645, 08028-Barcelona,Spain; E-mails: mar.ferrer.suay@gmail.com \& jpujade@ub.edu

J. Selfa, Universitat de València, Facultat de Ciències Biològiques, Departament de Zoologia. Campus de Burjassot-Paterna, Dr. Moliner 50, E-46100 Burjassot (València), Spain; E-mail: jesus.selfa@uv.es

M. V. Seco, Universidad de León, Escuela Superior y Técnica de Ingeniería Agraria, Dpto. de ingeniería agraria. Avda. de Portugal, 41, 24071-León, Spain. E-mail: victoriaseco@unileon.es

Received 30 October 2012, accepted 5 November 2013

\section{Introduction}

Charipinae is a cosmopolitan subfamily, being widely present in all biogeographic regions. This is a very complicated group with 281 described species, of which 168 are considered valid (Ferrer-Suay et al. 2012a). In the Scandinavian region 36 Charipinae species have been already cited: 29 in Sweden, 26 in Finland and 8 in Norway, by different authors (Zetterstedt 1838, Thomson 1862, Dalla Torre \& Kieffer 1910, Hellén 1931, 1963, 1966, Pujade-Villar et al.
2007, Westrum et al. 2010, Paretas-Martínez et al. 2011).

Alloxysta Förster, 1869 is the most speciesrich and widespread genus within the subfamily Charipinae. Alloxysta species, when known, are biologically characterized by being hyperparasitoids of aphids (Hemiptera: Aphididae) via Aphidiinae (Hymenoptera: Ichneumonoidea, Braconidae) and Aphelininae (Hymenoptera: Chalcidoidea, Aphelinidae) (Menke \& Evenhuis 1991).

Morphologically Alloxysta species are char- 
Fig. 1. Alloxysta apteroidea, holotype. a. Mesoscutum, dorsal view. - b. Antenna. - c. Pronotum. - d. Body. e. Propodeum.

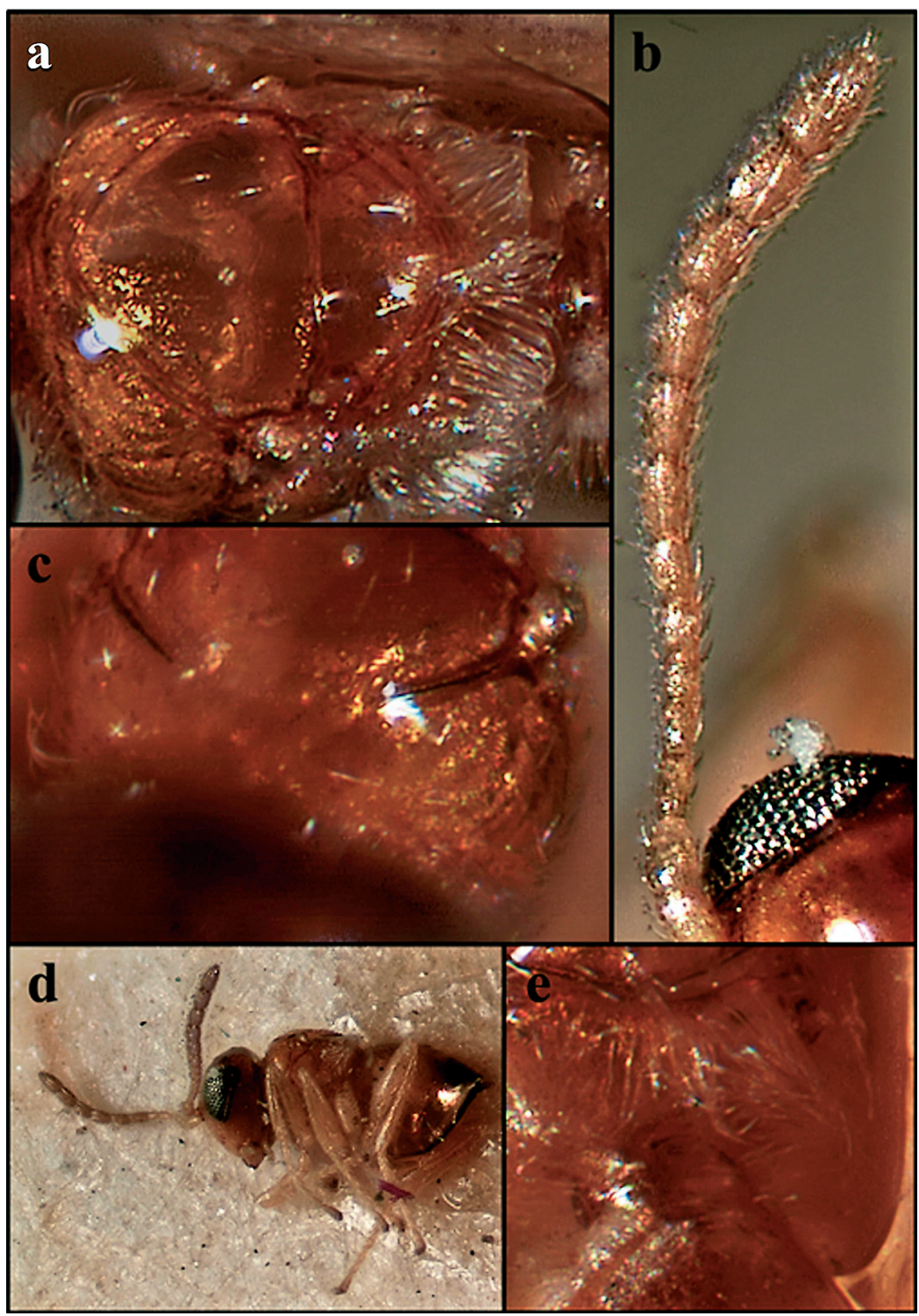

acteristically very small wasps $(0.8-2.0 \mathrm{~mm})$, with smooth and shiny body and with few diagnostic features useful to identify at species level. There are 172 described species in the genus of which 111 are nowadays considered valid (Ferrer-Suay et al. 2012a). The characters used by the earliest authors are not very clear and they were mainly based on the size and colour of specimens, characters later established as very variable within this group. This fact has led to a taxonomically very crowded and chaotic genus.

The identification of Alloxysta species is very difficult because of the reasons explained above; therefore a complete revision of this genus is needed. The first step to establish the real limits between the species and to know their main diagnostic characters is to study the type material deposited in different international institutions. We have already studied several Charipinae collections in order to revise the Alloxysta type material: Thomson $(1862,1877)$ and Zettersted (1838) (Ferrer-Suay et al. 2013), Hartig (1840, 1841), Belizin (1962, 1966, 1968, 1973) (Ferrer-Suay et al. 2012b), and Curtis (1838) (Ferrer-Suay et al. 2013b).

The main aim of the present paper is to revise 
the Hellén's Alloxysta type material deposited in the Finnish Museum of Natural History (Helsinki, Finland), and the Göteborg Naturhistoriska Museet (Göteborg, Sweden). Hellén described a total of 9 Alloxysta species, two of them in Hellén (1931): Alloxysta islandica and A. ruthei, and 7 more in Hellén (1963): Alloxysta apteroidea, A. brachycera, A. glebaria, A. heptatoma, A. nigricans, A. patens and A. soluta. Seven of these species are considered valid and they are here redescribed and illustrated. These redescriptions are needed, because the original ones were very short, focusing on irrelevant characteristics and not taking into account important features nowadays used to distinguish the species. Nowadays, the characters useful to distinguish Alloxysta species are: i) proportions of antennal flagellomeres, ii) size and shape of radial cell, iii) presence or absence of pronotal carinae, and iv) presence or absence of propodeal carinae, and their shape (Ferrer-Suay et al. 2011).

\section{Material and methods}

The studied specimens were loaned from MZH: Finnish Museum of Natural History (Helsinki, Finland), and GNM: Göteborg Naturhistoriska Museet (Göteborg, Sweden).

The specimens were studied using stereomicroscopy (NIKON SMZ-1). The images were obtained with a Zeiss Discovery V8 compound microscope with an attached INFINITYX-21C digital camera that fed image data to a notebook or desktop computer. The program DeltaPix View-Pro AZ was then used to merge an image series (typically representing 20 focal planes) into a single in-focus image. All photos were taken from the type material. The labels of the type specimens were scanned with a HP Deskjet 3050 print scan copy.

The morphological terms used are drawn from Paretas-Martínez et al. (2007). Measurements and abbreviations include F1-F12, i.e. the first and subsequent flagellomeres. The width of the forewing radial cell is measured from the margin of the wing to the beginning of the Rs vein. The transfacial line is the distance between the inner margins of the compound eyes, measured across the face through the antennal sockets. The

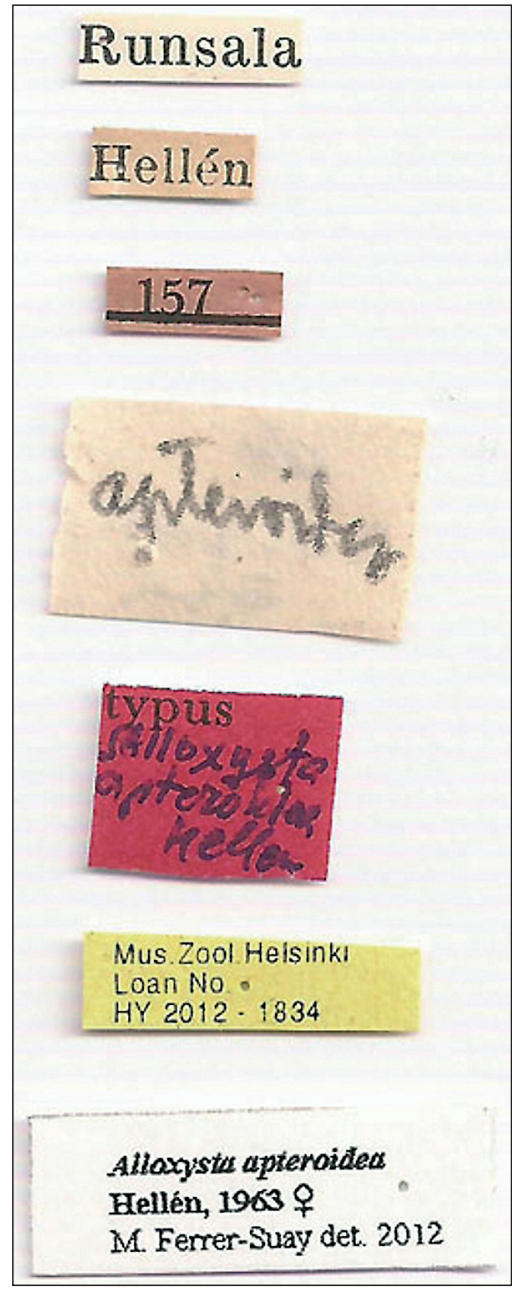

Fig. 2. Labels of Alloxysta apteroidea, holotype.

malar space is the distance from the mouthparts to the ventral margin of the compound eye. Females and males of the species described have the same characters except when indicated in the re-descriptions. The species are mentioned in alphabetical order.

\section{Revision of Hellén types of Alloxysta}

\subsection{Alloxysta apteroidea Hellén, 1963 (Fig. 1)}

Type material. Holotype $\bigcirc$ : In MZH with the following labels (Fig. 2): "Runsala", "Hellén", "157", "apteroidea" (handwritten), "Typus Alloxysta apteroidea Hellén" (handwritten), (red label), "Mus. Zool. Helsinki, Loan No. HY 2012- 
Fig. 3. Alloxysta brachycera, holotype. a. Forewing. - b. Pronotum. - c. Antenna. d. Propodeum.

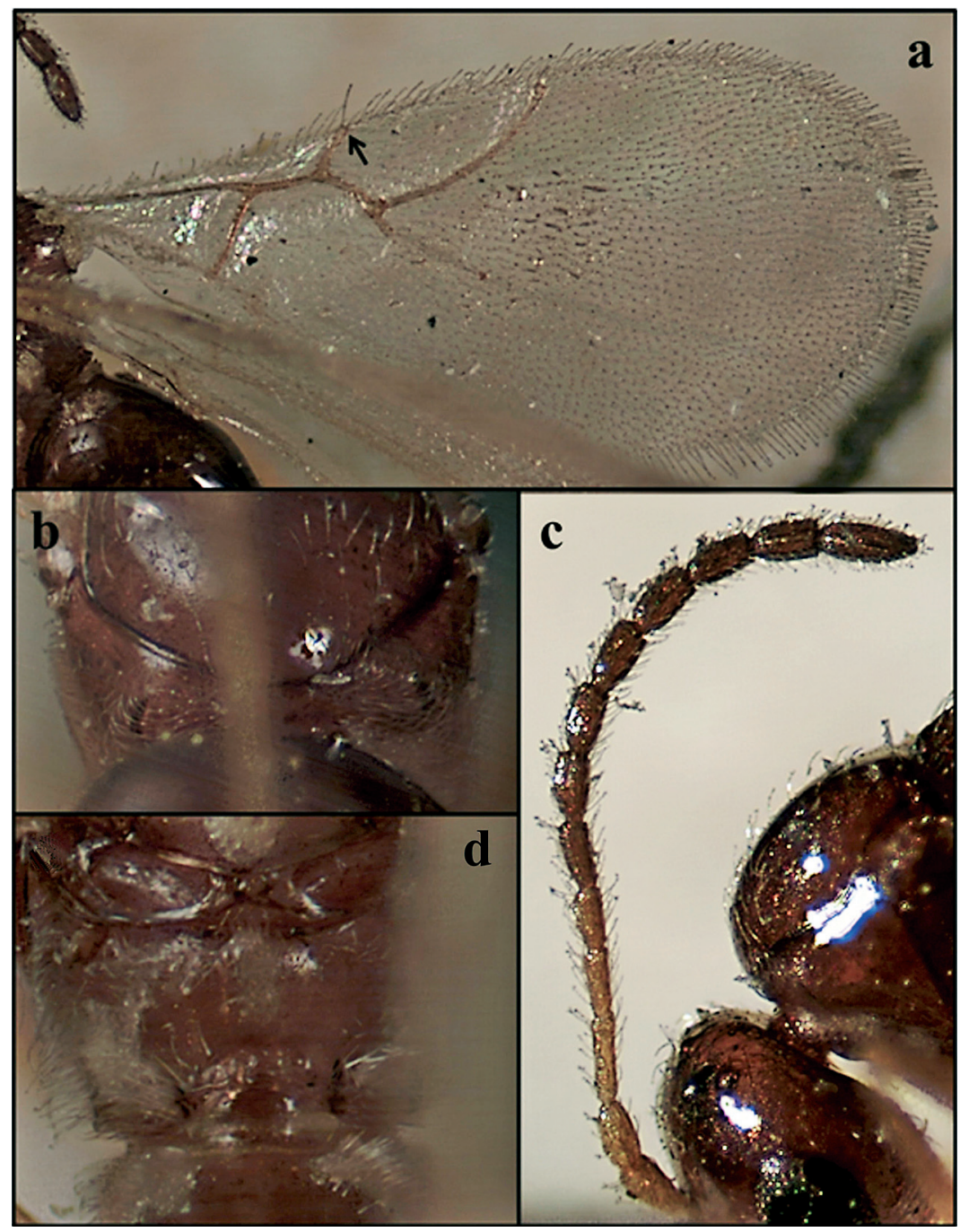

1834" (yellow label), "Alloxysta apteroidea Hellén, 1963 M. Ferrer-Suay det. 2012”.

Diagnosis. Alloxysta apteroidea is mainly characterized by being a brachypterous species, not having pronotal and propodeal carinae. It is similar to Alloxysta pedestris (Curtis, 1838) but they can be differentiated by the length of the forewing, which is very short and practically absent in A. apteroidea (Fig. 1a), but reaching the beginning of the metasoma in A. pedestris; and by the relation between pedicel and F1: pedicel longer than $\mathrm{F} 1$ in $A$. apteroidea (Fig. 1b) while shorter than $\mathrm{F} 1$ in $A$. pedestris.

Redescription. Colouration. Head, mesosoma and metasoma yellowish brown. Antennae yel- low darkening towards the end. Legs yellow.

Head. Transversally ovate, smooth and shiny, slightly wider than high in front view. Setae below, between and a few above toruli. Few scattered setae on vertex and many setae on face. Transfacial line 1.1 times the height of compound eye. Malar space 0.5 times the height of compound eye.

Antenna. 13-segmented, filiform. All antennomeres covered with sparse setae. F1-F5 thinner and smoother than remaining flagellomeres, F6-F11 with rhinaria and club-shaped. Pedicel 1.5 times as long as wide, F1 2.2 times as long as wide, F2 1.4 times as long as wide, F3 1.3 times as long as wide, F4 1.4 times as long as wide. 
Pedicel 1.1 times as long as F1, F1 1.4 times as long as F2, F2 subequal to F3, F4 1.1 times as long as F3, F4-F11 subequal in length, width and shape (Fig. 1b).

Mesosoma. Pronotum covered by few setae, without carinae (Fig. 1c). Mesoscutum smooth and shiny, round in dorsal view with few scattered setae (Fig. 1a). Scutellum also smooth and shiny with few scattered setae, more abundant on apex of scutellum. Propodeum covered by many setae, without carinae (Fig. 1e).

Forewing. Shorter than body (Fig. 1a). Without radial cell.

Metasoma. Anterior part with an incomplete ring of setae, glabrous at centre, wider laterally. Metasoma smooth and shiny, T3 and T4 clearly distinguished.

Male. Unknown.

\subsection{Alloxysta brachycera Hellén, 1963 (Fig. 3)}

Type material. Holotype $\bigcirc$ : In MZH with the following labels (Fig. 4): "Nystad", "Hellén”, “61”, "brachycera" (handwritten), "typus" (red label), "Mus. Zool. Helsinki, Loan No. HY 2012-1830" (yellow label), "Alloxysta brachycera Hellén, 1963 o M. Ferrer-Suay det. 2012”.

Diagnosis. Alloxysta brachycera is mainly characterized by having completely open radial cell, pronotal carinae present, propodeal carinae absent, F4-F11 with rhinaria and club-shaped. According to these features, A. brachycera is very similar to Alloxysta nigrita (Thomson, 1862) but they can be differentiated by the relation between $\mathrm{F} 2 / \mathrm{F} 3$ : $\mathrm{F} 2$ is longer than $\mathrm{F} 3$ in $A$. brachycera (Fig. 3c) while F2 is shorter than F3 in A. nigrita.

Redescription. Colouration. Head, mesosoma and metasoma brown. Scape, pedicel, F1-F3 yellow, F4-F11 yellowish brown. Legs yellow and veins yellowish brown.

Head. Transversally ovate, smooth and shiny, slightly wider than high in front view. Setae below, between and a few above toruli. Without setae on vertex and many setae on face. Transfacial line 1.2 times the height of compound eye. Malar space 0.4 times the height of compound eye.

Antenna. 13-segmented, filiform. All anten-

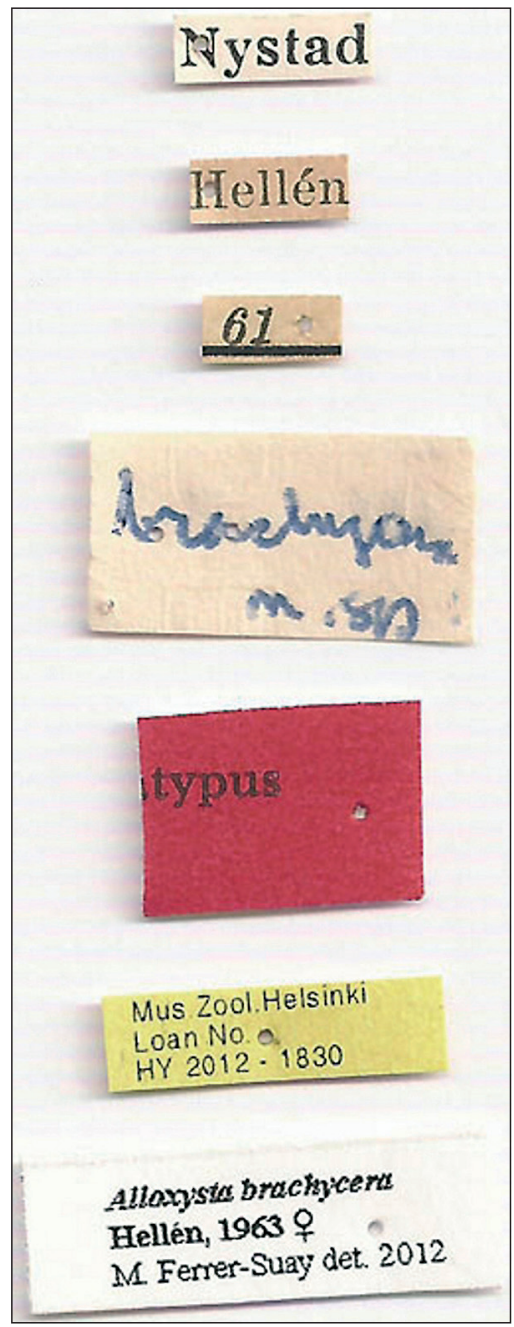

Fig. 4. Labels of Alloxysta brachycera, holotype.

nomeres covered with sparse setae. F1-F3 thinner and smoother than remaining flagellomeres, F4-F11 with rhinaria and club-shaped. Pedicel 1.7 times as long as wide, F1 4.2 times as long as wide, F2 2.8 times as long as wide, F3 2.1 times as long as wide, F4 2.4 times as long as wide. F1 1.3 times as long as pedicel, F1 1.3 times as long as F2, F2 1.1 times as long as F3, F4 1.2 times as long as F3, F4-F11 subequal in length, width and shape (Fig. 3c).

Mesosoma. Pronotum covered by scattered setae, less abundant on distolateral margins, two thick carinae clearly visible (Fig. 3b). Mesoscutum smooth and shiny, round in dorsal view with few scattered setae. Scutellum also smooth and shiny with few scattered setae, more abundant on 


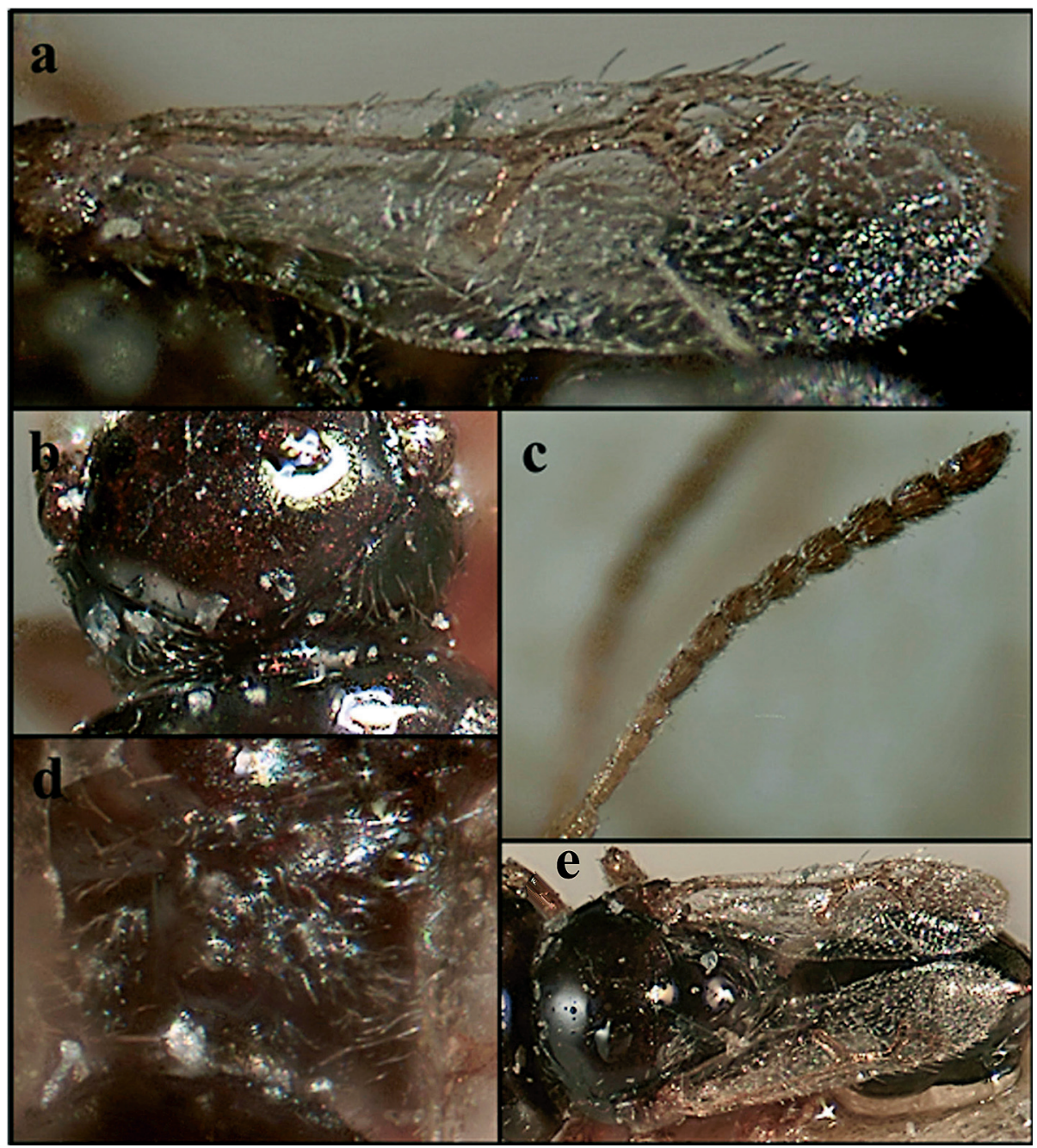

Fig. 5. Alloxysta glebaria, holotype. - a. Forewing. - b. Pronotum. - c. Antenna. - d. Propodeum. - e. Mesoscutum, dorsal view.

apex of scutellum. Propodeum covered by setae, less abundant in central area, without carinae (Fig. 3d).

Forewing. Longer than body, 1.8 times as long as mesosoma and metasoma together. Covered with dense pubescence, marginal setae present. Completely open radial cell, 2.7 times as long as wide. R1 short and straight, Rs long and curved (Fig. 3a).

Metasoma. Anterior part with an incomplete ring of setae, glabrous at centre, wider laterally. Metasoma smooth and shiny, T3 and T4 clearly distinguished.

Male. Unknown.

Comments. Alloxysta brachycera and Allo- xysta nigrita are very similar, differing only in one antennal character. These differences could be associated with intraspecific divergence and then maybe in the future the species could be synonymized. However, due to the few specimens revised the two species remain as valid in this study.

\subsection{Alloxysta fuscipes (Thomson, 1862) = Alloxysta ruthei Hellén, 1931}

Type material (as A. ruthei Hellén). Here designated; in GNM. Lectotype $O$ : With the following labels: "Typus" (handwritten), "95", "Allo- 
xysta ruthei m. + Hellén det.", "Alloxysta fuscipes c.g. Th. +, S. Jansoon det." (handwritten), "Lectotype Alloxysta ruthei Hellén, 1831 o desig. M. Ferrer-Suay 2012” (red label), "Alloxysta fuscipes (Thomson, 1862) ㅇ M. Ferrer-Suay det. 2012".

Paralectotypes, $10 \curvearrowright \& 3$ ㅇ : With the following labels: "167”, "Alloxysta ruthei m. đ̂ Hellén det.", "Alloxysta fuscipes c.g. Th. $\mathrm{o}$, S. Jansoon det." (handwritten), "Paralectotype Alloxysta ruthei Hellén, 1831 ऽ̋ M. Ferrer-Suay 2012" (red label), "Alloxysta fuscipes (Thomson, 1862) $\widehat{\sigma}$ M. Ferrer-Suay det. 2012": 1ठ; "167”, "Paralectotype Alloxysta ruthei Hellén, 1831 ఠิ M. Ferrer-Suay 2012" (red label), "Alloxysta fuscipes (Thomson, 1862) $\lesssim$ M. Ferrer-Suay det. 2012": 7ð’; “167”, "Paralectotype Alloxysta ruthei Hellén, 1831 O M. Ferrer-Suay 2012” (red label), "Alloxysta fuscipes (Thomson, 1862) q M. Ferrer-Suay det. 2012": 3; “170”, "Paralectotype Alloxysta ruthei Hellén, 1831 ठै M. Ferrer-Suay 2012" (red label), "Alloxysta fuscipes (Thomson, 1862) ð M. Ferrer-Suay det. 2012": $2{ }^{\Uparrow}$.

Comments. Alloxysta ruthei was synonymized with Alloxysta fuscipes (Thomson, 1862) by Weld (1952: 253). Type material of $A$. ruthei has been revised and the synonymy with $A$. fuscipes is confirmed. The lectotype is designated here and the paralectotypes are also established. Complete description, diagnosis and plate of $A$. fuscipes are given in Ferrer-Suay et al. (2013).

\subsection{Alloxysta glebaria Hellén, 1963 (Fig. 5)}

Type material. Holotype 9 : In MZH with the following labels (Fig. 6): "Hammarland", "Hellén", “4622", "Typus Alloxysta glebaria Hellén" (handwritten), (red label), "Sp2", the rest not understandable (handwritten), "glebaria" (handwritten), "Mus. Zool. Helsinki, Loan No. HY 2012 -1827" (yellow label), "Alloxysta glebaria Hellén, 1963 O M. Ferrer-Suay det. 2012”.

Diagnosis. Alloxysta glebaria is mainly characterized by being brachypterous species with radial cell present. According to this feature, $A$. glebaria is very similar to Alloxysta marshalliana (Kieffer, 1900) but they can be easily differentiated by the shape of the radial cell, which is closed in A. glebaria (Fig. 5a) while completely

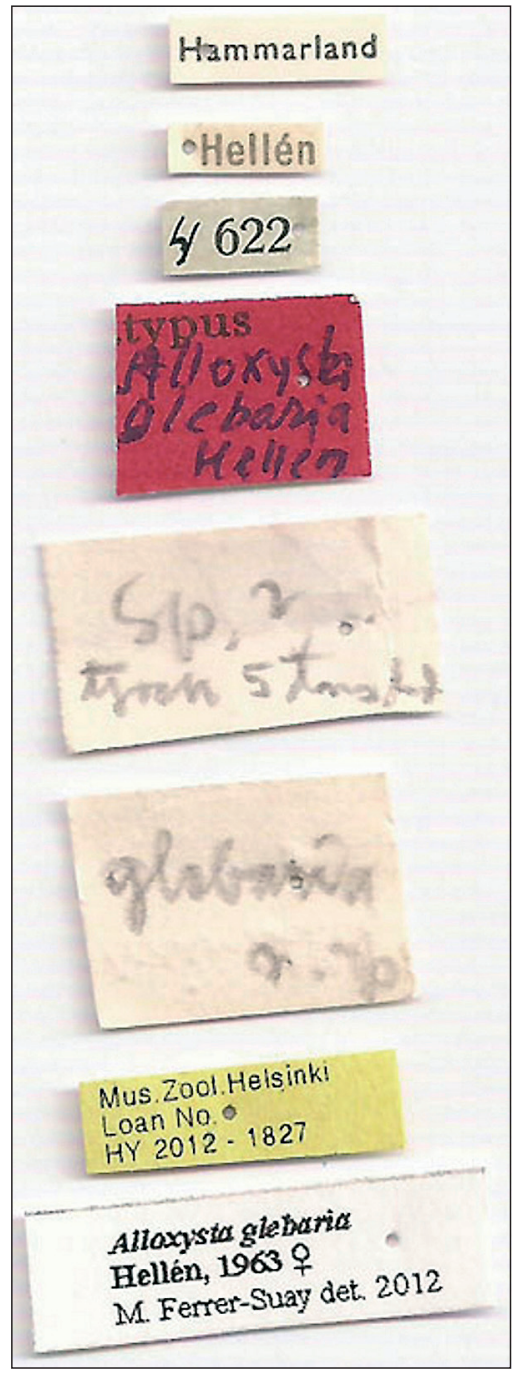

Fig. 6. Labels of Alloxysta glebaria, holotype.

open in A. marshalliana.

Redescription. Colouration. Head, mesosoma and metasoma brown. Scape yellowish brown, pedicel, F1-F3 yellow, F4-F11 yellowish brown. Legs yellow and veins yellowish brown.

Head. Transversally ovate, smooth and shiny, slightly wider than high in front view. Setae below, between and a few above toruli. Without or with few setae on vertex and many setae on face. Transfacial line 1.1 times the height of compound eye. Malar space 0.4 times the height of compound eye.

Antenna. 13-segmented, filiform. All antennomeres covered with sparse setae. F1-F3 thinner and smoother than remaining flagellomeres, 


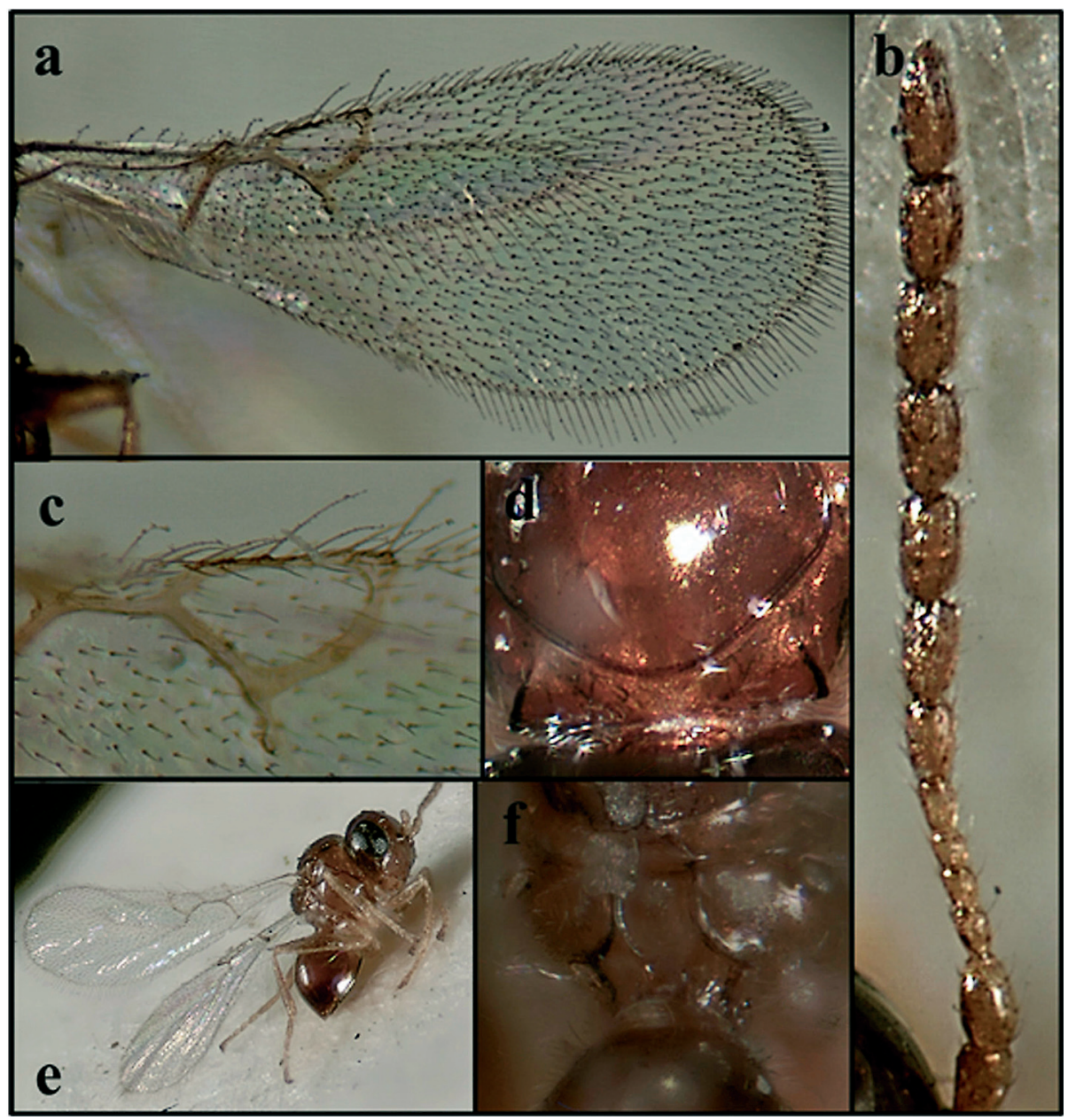

Fig. 7. Alloxysta heptatoma, holotype. - a. Forewing. - b. Antenna. - c. Radial cell. - d. Pronotum. - e. Body. - f. Propodeum.

F4-F11 with rhinaria and club-shaped. Pedicel 1.7 times as long as wide, F1 2.7 times as long as wide, F2 1.8 times as long as wide, F3 1.3 times as long as wide, F4 1.8 times as long as wide. F1 subequal to pedicel, F1 1.3 times as long as F2, F2 1.3 times as long as F3, F4 1.6 times as long as F3, F4-F11 subequal in length, width and shape (Fig. $5 c)$.

Mesosoma. Pronotum covered by setae, less abundant on distolateral margins, without carinae (Fig. 5b). Mesoscutum smooth and shiny, round in dorsal view with few scattered setae. Scutellum also smooth and shiny with few scattered setae, more abundant on apex of scutellum. Propodeum covered by setae, two carinae forming a plate, with few setae on top (Fig. 5d).
Forewing. Shorter than body, 0.7 times as long as mesosoma and metasoma together. Covered with dense pubescence, marginal setae present. Closed radial cell, 2.2 times as long as wide. R1 and Rs slightly curved (Fig. 5a).

Metasoma. Anterior part with an incomplete ring of setae, glabrous at centre, wider laterally. Metasoma smooth and shiny, T3 and T4 clearly distinguished.

Male. Unknown.

\subsection{Alloxysta heptatoma Hellén, 1963 (Fig. 7)}

Type material. Holotype $\bigcirc$ : In MZH with the following labels (Fig. 8): "Dragsfjärd", "Fennia", "Hellén", "4032", "heptatoma m" (handwritten), 


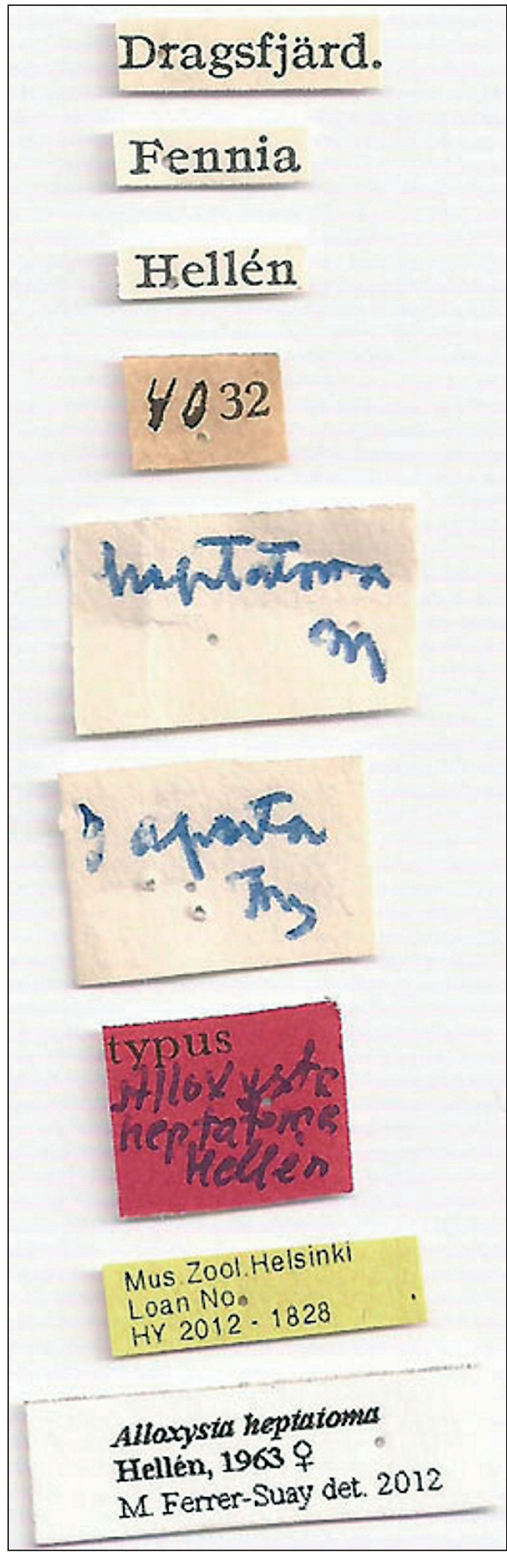

Fig. 8. Labels of Alloxysta heptatoma, holotype.

"aperta Hg" (handwritten), "typus Alloxysta heptatoma Hellén" (hadwritten), (red label), "Mus. Zool. Helsinki, Loan No. HY 2012-1828" (yellow label), "Alloxysta heptatoma Hellén, 1963 M. Ferrer-Suay det. 2012”.

Diagnosis. Alloxysta heptatoma is mainly characterized by having small closed radial cell, pronotal carinae present, propodeal carinae well defined with sharp edges, F5-F11 with rhinaria and club-shaped. There are no similar Alloxysta species.

Redescription. Colouration. Head, mesosoma and metasoma yellowish brown. Scape, pedicel, F1-F4 yellow, F5-F11 yellowish brown. Legs yellow and veins yellowish brown.

Head. Transversally ovate, smooth and shiny, slightly wider than high in front view. Setae below and above toruli, few setae between toruli. Scattered setae on vertex and many setae on face. Transfacial line 1.1 times the height of compound eye. Malar space 0.4 times the height of compound eye.

Antenna. 13-segmented, filiform. All antennomeres covered with sparse setae. F1-F4 thinner and smooth than remaining flagellomeres, F5-F11 with rhinaria and club-shaped. Pedicel 1.8 times as long as wide, F1 1.3 times as long as wide, F2 1.4 times as long as wide, F3 1.5 times as long as wide, F4 1.5 times as long as wide. Pedicel 2.1 times as long as F1, F1-F3 subequal in length, F4 1.2 times as long as F3, F5 1.4 times as long F4, F5-F11 subequal in length, width and shape (Fig. 7b).

Mesosoma. Pronotum covered by scattered setae, more abundant on anterior margins; with two thick carinae clearly visible (Fig. 7d). Mesoscutum smooth and shiny, round in dorsal view with few scattered setae. Scutellum also smooth and shiny with few scattered setae, more abundant on apex of scutellum. Propodeum covered by setae, with two carinae well defined, thin in the first half and thick in the last third, with sharp edges (Fig. 7f).

Forewing. Longer than body, 1.1 times as long as mesosoma and metasoma together (Fig. 7a). Covered with dense pubescence, marginal setae present. Closed radial cell, 1.9 times as long as wide. R1 short and straight, Rs longer and curved (Fig. 7c).

Metasoma. Anterior part with an incomplete ring of setae, glabrous at centre, wider laterally. Metasoma smooth and shiny, T3 and T4 clearly distinguished.

Male. Unknown.

\subsection{Alloxysta nigricans Hellén, 1963 (Fig. 9)}

Type material. Holotype 9 : In MZH with the following labels (Fig. 10): "Taipalsaari", "Fennia", "Hellén", "2920", not understandable (handwritten), "nigricans m" (handwritten), "Holotypus" 


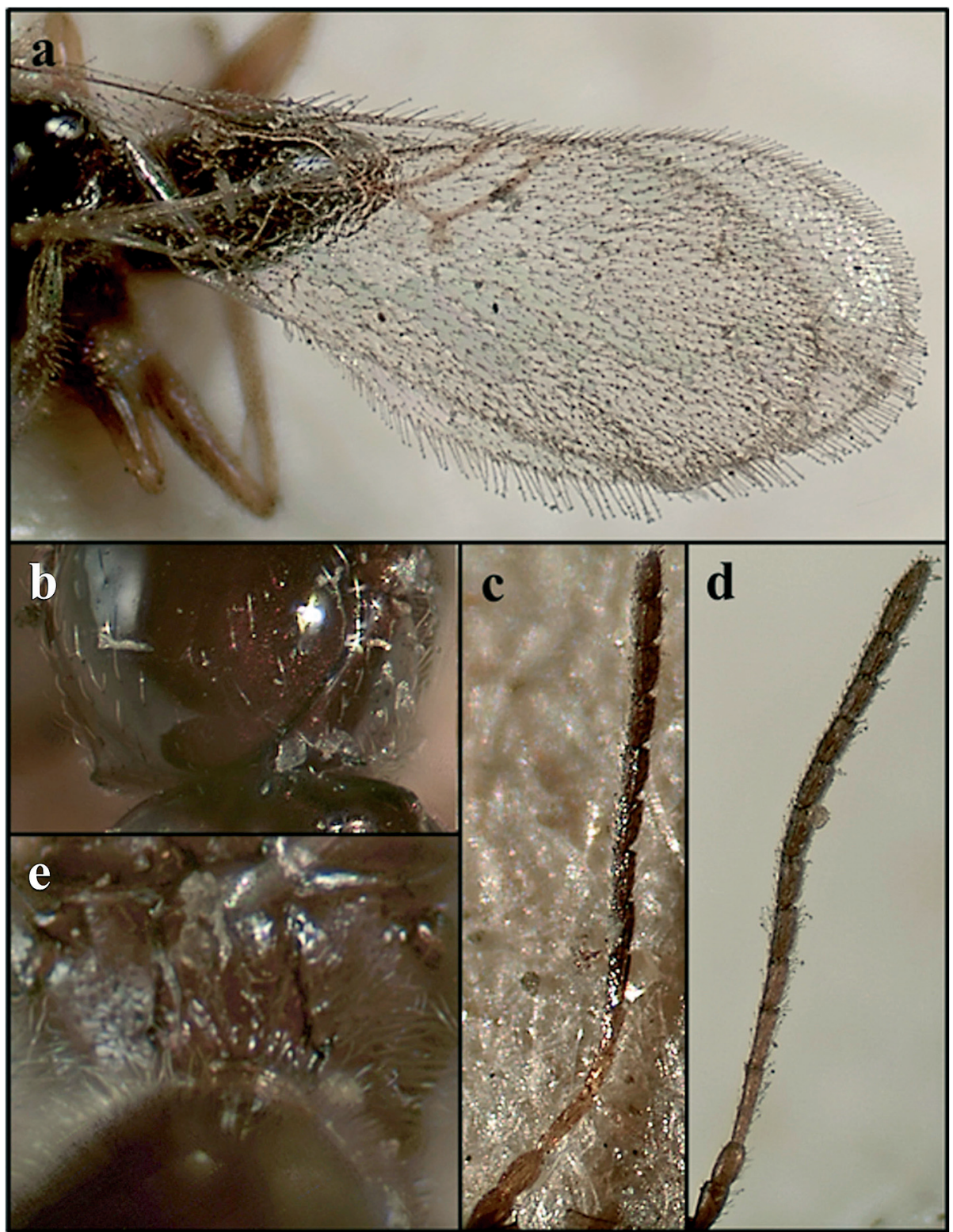

Fig. 9. Alloxysta nigricans, holotype and paratype. - a. Forewing. - b. Pronotum. - c. Antenna, male. - d. Antenna, female. - e. Propodeum.

(red label), "Mus. Zool. Helsinki, Loan No. HY 4122", (ornage label), "Mus. Zool. Helsinki, Loan No HY 2012-1831" (yellow label), “Alloxysta nigricans Hellén, 1963 M. FerrerSuay det. 2012".

Paratype ${ }^{\lambda}$ : In MZH with the following labels (Fig. 10): "Lojo", "Forsius", "20 206”, “”", “? nigrescens" (handwritten), "Paratypus Alloxysta nigricans Hellén" (handwritten), (red label),
"Mus. Zool. Helsinki, Loan No. HY 2012-1833" (yellow label), “Alloxysta nigricans Hellén, 1963 స M. Ferrer-Suay det. 2012".

Diagnosis. Alloxysta nigricans is mainly characterized by having closed radial cell, pronotal carinae and propodeal plate present, F4 F12 with rhinaria and club-shaped in both male and female and F1 longer than pedicel. There are no similar Alloxysta species. 


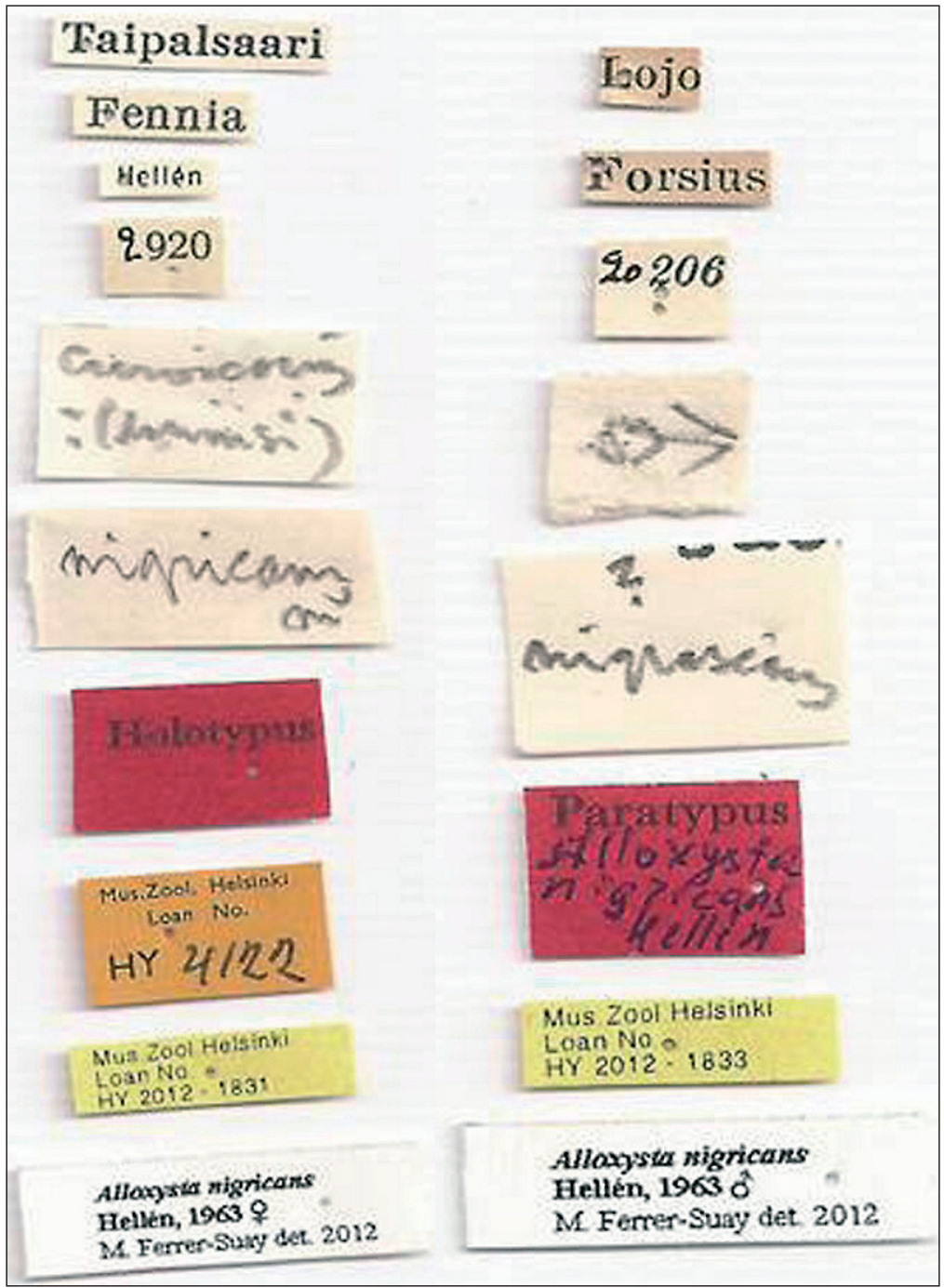

Fig. 10. Labels of Alloxysta nigricans, holotype and paratype.
Redescription. Colouration. Head, mesosoma and metasoma dark brown. Scape yellowish brown, pedicel and F1-F3 yellow, F4-F12 yellowish brown. Legs yellow and veins yellowish brown.

Head. Transversally ovate, smooth and shiny, slightly wider than high in front view. Setae below and between toruli, without setae above toruli. Without or with few setae on vertex and many setae on face. Transfacial line 0.9 times the height of compound eye. Malar space 0.5 times the height of compound eye.

Antenna. Female: 13-segmented, filiform. All antennomeres covered with sparse setae. F1-F3 thinner and smoother than remaining flagello- meres, F4-F11 with rhinaria and club-shaped. Pedicel 1.7 times as long as wide, F1 4.2 times as long as wide, F2 3.4 times as long as wide, F3 2.6 times as long as wide, F4 2.1 times as long as wide. F1 1.6 times as long as pedicel, F1 1.2 times as long as F2, F2 1.1 times as long as F3, F3-F11 subequal in length, width and shape (Fig. 9d). Male: 14-segmented, filiform. All antennomeres covered with sparse setae. F1-F3 thinner and smoother than remaining flagellomeres, F4-F12 with rhinaria and club-shaped. Pedicel 1.5 times as long as wide, F1 3.6 times as long as wide, F2 2.2 times as long as wide, F3 2.3 times as long as wide, F4 2.9 times as long as wide. F1 1.5 times as long as pedicel, F1 1.9 times as long as F2, F3 1.1 


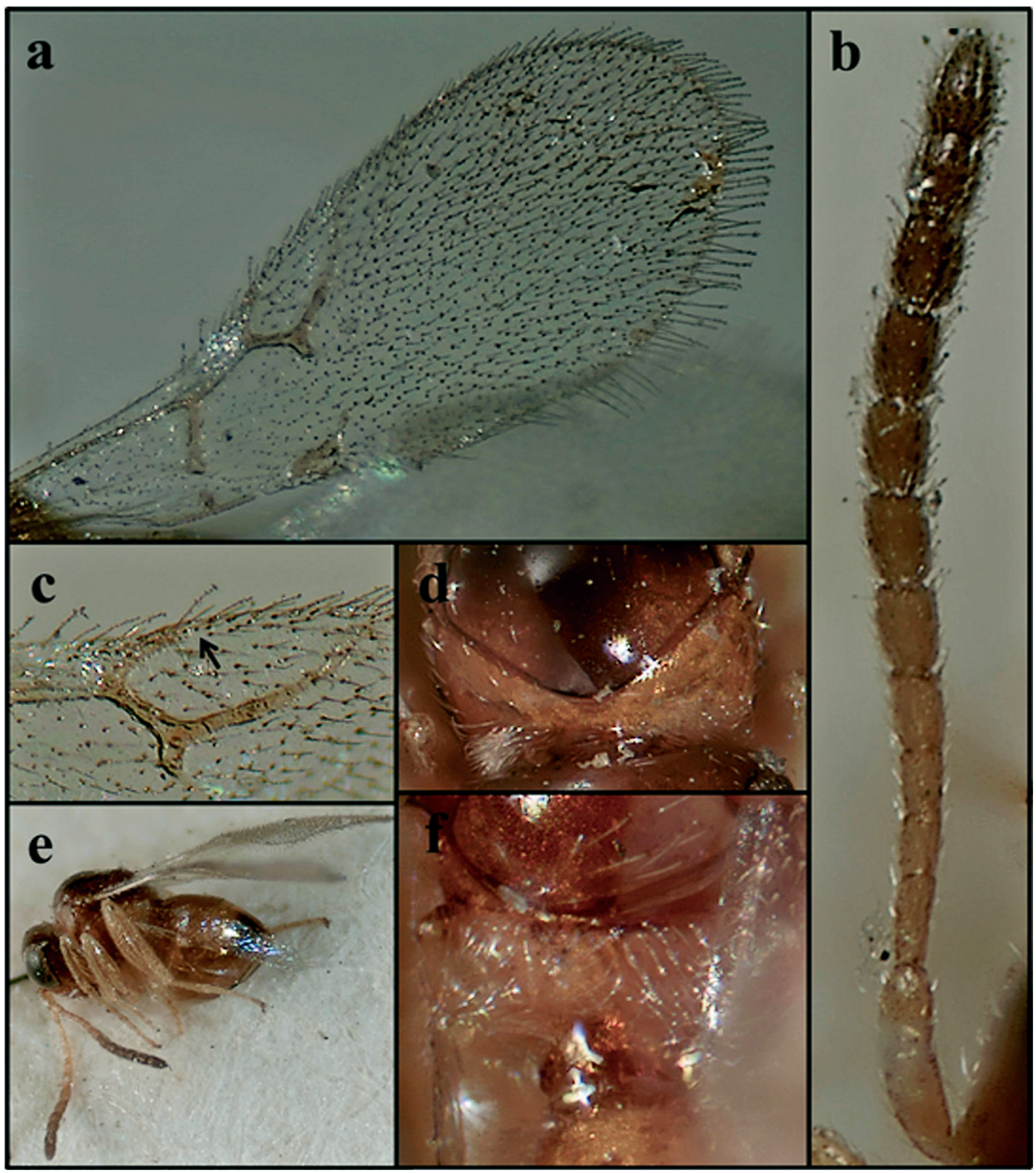

Fig. 11. Alloxysta patens, holotype. - a. Forewing. - b. Antenna. - c. Radial cell. - d. Pronotum. - e. Body. - f. Propodeum.

times as long as F2, F4 1.2 times as long as F3, F4-F12 subequal in length, width and shape (Fig. 9c).

Mesosoma. Pronotum covered by scattered setae, with two thick carinae clearly visible (Fig. $9 \mathrm{~b})$. Mesoscutum smooth and shiny, round in dorsal view with few scattered setae. Scutellum also smooth and shiny with few scattered setae, more abundant on apex of scutellum. Propodeum cov- ered by setae, two carinae forming a plate with few setae on top and two divergent peaks at the base (Fig. 9e).

Forewing. Longer than body, 1.3 times as long as mesosoma and metasoma together. Covered with dense pubescence, marginal setae present. Closed radial cell, 2.7 times as long as wide in both male and female. R1 short and slightly curved, Rs longer and curved (Fig. 9a). 
Metasoma. Anterior part with an incomplete ring of setae, glabrous at center, wider laterally. Metasoma smooth and shiny, T3 and T4 clearly distinguished.

\subsection{Alloxysta patens Hellén, 1963 (Fig. 11)}

Type material. Holotype 9 : In MZH with the following labels (Fig. 12): "Hellén", "Houtskär", "830", "typus" (red label), "Alloxysta patens Hellén" (handwritten), "Mus. Zool. Helsinki Loan No. HY 2012-1835” (yellow label), “Alloxysta patens Hellén, 1963 + M. Ferrer-Suay det. 2012”.

Diagnosis. Alloxysta patens is mainly characterized by having partially open radial cell, pronotal carinae absent, propodeal carinae also absent, F4-F11 with rhinaria and club-shaped and F1 subequal to pedicel. There are no similar Alloxysta species.

Redescription. Colouration. Head, mesosoma and metasoma yellowish brown. Scape, pedicel, F1-F4 yellow, F5-F11 yellowish brown. Legs yellow and veins yellowish brown.

Head. Transversally ovate, smooth and shiny, slightly wider than high in front view. Setae below, between and above toruli. With scattered setae on vertex and many setae on face. Transfacial line and malar space cannot be measured due to the position of the type specimen.

Antenna. 13-segmented, filiform. All antennomeres covered with sparse setae. F1-F3 thinner and smoother than remaining flagellomeres, F4-F11 with rhinaria and club-shaped. Pedicel 1.7 times as long as wide, F1 2.7 times as long as wide, F2 1.5 times as long as wide, F3 1.4 times as long as wide, F4 1.7 times as long as wide. F1 subequal to pedicel, F1 1.5 times as long as F2, F2 subequal to F3, F4 1.4 times as long as F3, F4 F11 subequal in length, width and shape (Fig. 11b).

Mesosoma. Pronotum covered by scattered setae, abundant on anterior margin, without carinae (Fig. 11d). Mesoscutum smooth and shiny, round in dorsal view with few scattered setae. Scutellum also smooth and shiny with few scattered setae, more abundant on apex of scutellum. Propodeum covered by abundant setae, without carinae (Fig. 11f).

Forewing. Longer than body, 1.5 times as

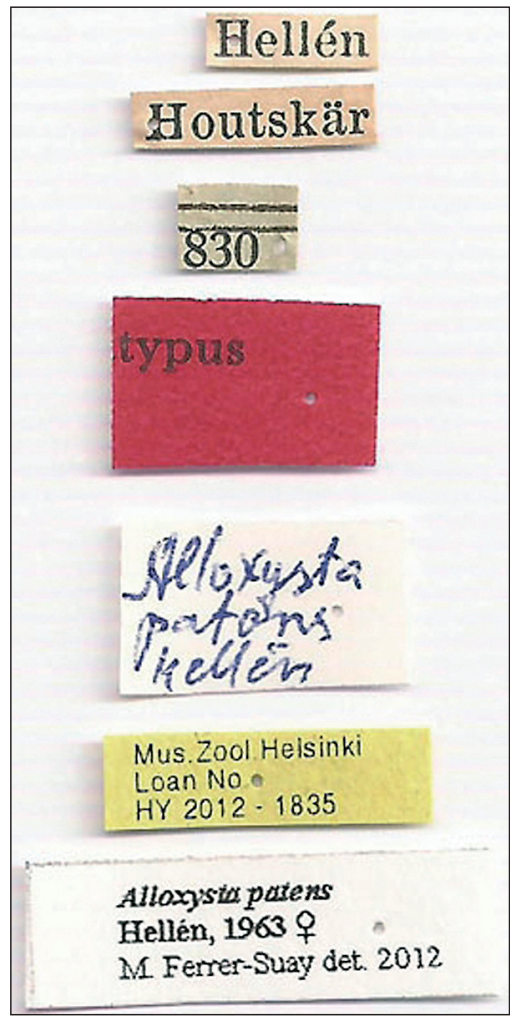

Fig. 12. Labels of Alloxysta patens, holotype.

long as mesosoma and metasoma together (Fig. 11a). Covered with dense pubescence, marginal setae present. Partially open radial cell, 2.8 times as long as wide. R1 short and slightly curved, Rs longer and curved, not reaching the margin of the forewing (Fig. 11c).

Metasoma. Anterior part with an incomplete ring of setae, glabrous at center, wider laterally. Metasoma smooth and shiny, T3 and T4 clearly distinguished.

Male. Unknown.

\subsection{Alloxysta soluta Hellén, 1963 (Fig. 13)}

Type material. Designated here; in $\mathrm{MZH}$. Lectotype $O$ : With the following labels (Fig. 14): "Jomala", "Fennia", "Hellén", "2313", “typus" (red label), "Alloxysta soluta Hell." (handwritten), "Mus. Zool. Helsinki Loan No. HY 4113" (orange label), "Mus. Zool. Helsinki Loan No. HY 2012-1832" (yellow label), "Lectotype Alloxysta soluta Hellén, 1863 q desig. M. FerrerSuay 2012" (red label), "Alloxysta soluta Hellén, 1963 + M. Ferrer-Suay det. 2012”. 


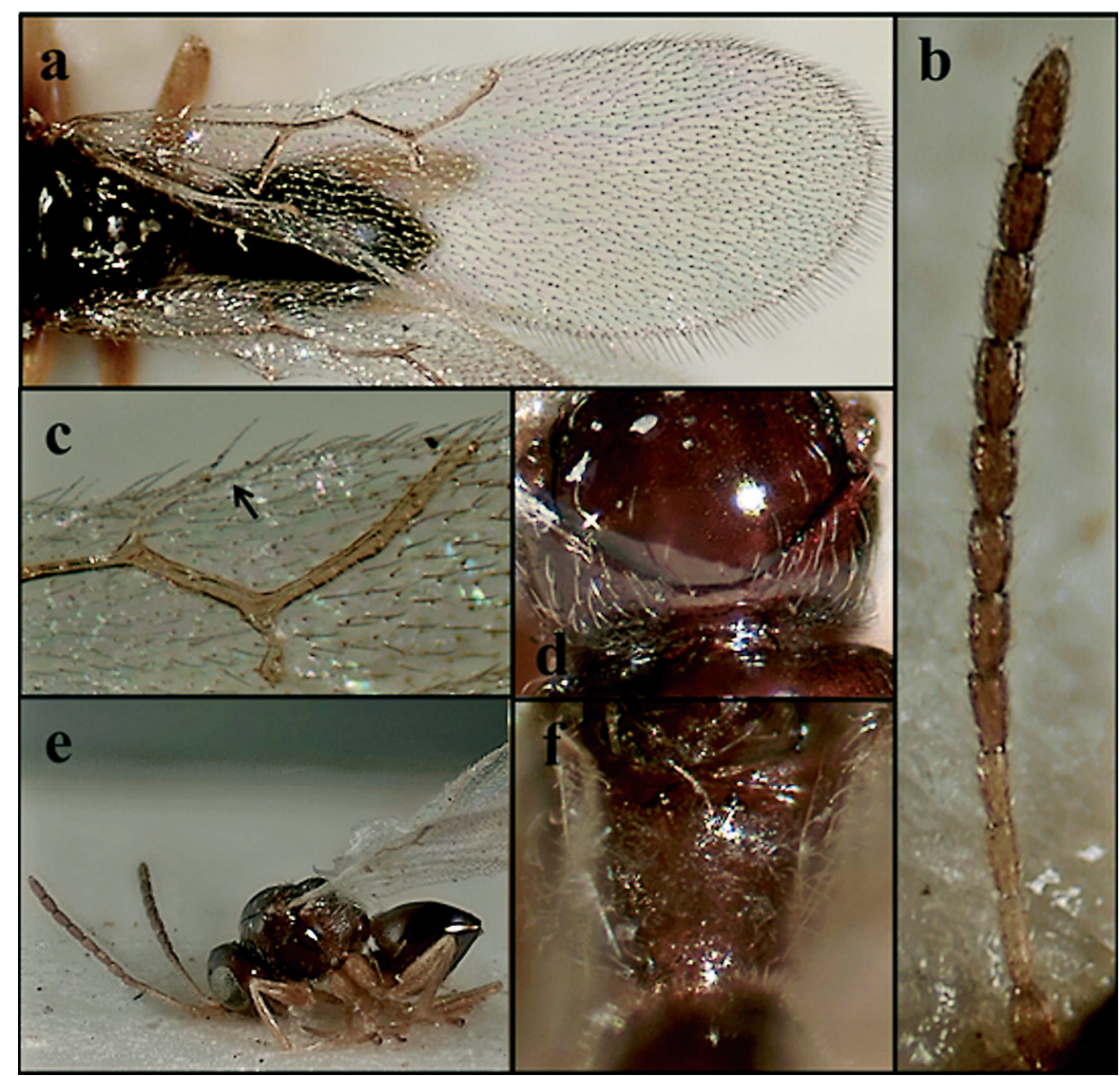

Fig. 13. Alloxysta soluta, lectotype. - a. Forewing. - b. Antenna. - c. Radial cell. - d. Pronotum. - e. Body. - f. Propodeum.

Paralectotype ${ }^{\circ}$ : With the following labels (Fig. 14): "Jomala", "Hellén", "Fennia", "1645", "soluta m" (handwritten), "typus" (red label), "Mus. Zool. Helsinki Loan No. HY 2012-1829" (yellow label), "Paralectotype Alloxysta soluta Hellén, 1863 q M. Ferrer-Suay 2012" (red label), “Alloxysta soluta Hellén, 1963 † M. Ferrer-Suay det. 2012".

Diagnosis. Alloxysta soluta is mainly characterized by having partially open radial cell, pronotal carinae and propodeal carinae absent, F4-F11 with rhinaria and club-shaped and F1 longer than pedicel. There are no similar Alloxysta species.

Redescription. Colouration. Head, mesosoma and metasoma brown. Scape, pedicel, F1-F3 yellow; F4-F11 yellowish brown. Legs yellow and veins yellowish brown.

Head. Transversally ovate, smooth and shiny, slightly wider than high in front view. Setae below and above toruli, few setae between toruli. With scattered setae on vertex and many setae on face. Transfacial line and malar space cannot be measured due to the position of the type specimen.

Antenna. 13-segmented, filiform. All antennomeres covered with sparse setae. F1-F3 thinner and smoother than remaining flagellomeres, F4-F11 with rhinaria and club-shaped. Pedicel 1.6 times as long as wide, F1 3.0 times as long as wide, F2 2.5 times as long as wide, F3 2.5 times as long as wide, F4 1.9 times as long as wide. F1 1.3 times as long as pedicel, F1 1.2 times as long as F2, F2-F4 subequal in length, F4-F11 subequal in length, width and shape (Fig. 13b).

Mesosoma. Pronotum covered by long scattered setae, without carinae (Fig. 13d). Mesoscutum smooth and shiny, round in dorsal view with 


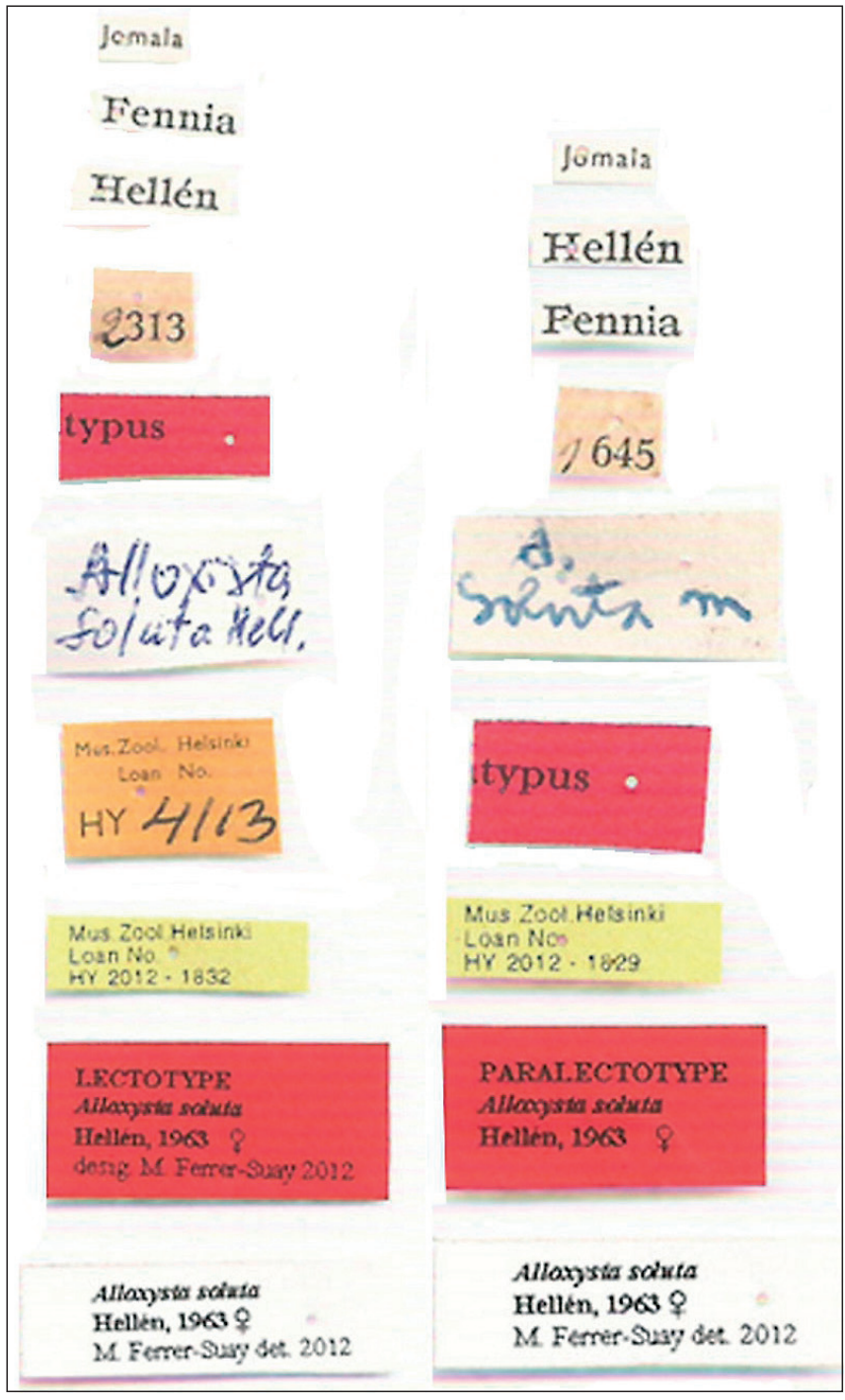

Fig. 14. Labels of Alloxysta soluta, lectotype and paralectotype. few scattered setae. Scutellum also smooth and shiny with few scattered setae, more abundant on apex of scutellum. Propodeum entirely covered by setae, without carinae (Fig. 13f).

Forewing. Longer than body, 1.6 times as long as mesosoma and metasoma together (Fig. 13a). Covered with dense pubescence, marginal setae present. Partially open radial cell, 2.3 times as long as wide. R1 short and slightly curved, Rs longer and also curved (Fig. 13c).

Metasoma. Anterior part with an incomplete ring of setae, glabrous at center, wider laterally. Metasoma smooth and shiny, T3 and T4 clearly distinguished.

Male. Unknown.

\subsection{Phaenoglyphis villosa (Hartig, 1841) = Alloxysta islandica Hellén, 1931 syn. n.}

Type material (as $A$. islandica Hellén). Lectotype $\rightarrow$ : Designated here; In GNM with the following labels: "167", "Alloxysta islandica m., Hellén det. †", "Lectotype Alloxysta islandica Hellén, 1831 + desig. M. Ferrer-Suay 2012” (red label), "Phaenoglyphis villosa (Hartig, 1841) q M. Ferrer-Suay det. 2012”.

Comments. Alloxysta islandica is here synonymized with $P$. villosa (Hartig, 1841). This specimen is clearly a Phaenoglyphis species because the mesopleural sulcus is present, and it is $P$. villosa because it has partially open radial cell, 
notauli not present and the same proportion between flagellomeres. This specimen had no type status, only the Hellén's determination. However, according to the original description it was based on only one specimen. For this reason, we designate this specimen as the lectotype of Alloxysta islandica.

Acknowledgements. We are very grateful to Dr. Olof Biström (MZH) and Dr. C. Jonsson (GNM) for the loan of the material here studied. This research was supported by the projects CGL2008-00180 and CGL2011-22889 of the Ministerio de Ciencia e Innovación (Spain) and the grant AP2009-4833 of the Ministerio de Educación (Spain).

\section{References}

Belizin, V. I. 1962: New Parasitoid Cynipoidea species (Hymenoptera) from a Far East. - Communications of the Far East Branch of the Russian Academy of Sciences (Siberian Section) 16: 125-129.

Belizin, V. I. 1966: Paraziticheskie tsinipidy (Hymenoptera, Cynipoidea) moldavskoj SSR (Parasitic Cynipids (Hymenoptera, Cynipoidea) in the Mmoldavian SSR). - Trudy Moldavskoho nauchono-issled. Instituta Sadovodstva, Vinogradarstva i Vinodelija (Entomologia) 13: 1-14.

Belizin, V. I. 1968: New genera and species of gall wasps (Hymenoptera, Cynipoidea) of the Soviet Far East and adjacent territories. - District Station of Plant Protection (Kursk) 5: 701-719.

Belizin, V. I. 1973: New Cynipids (Hymenoptera, Cynipoidea) from the USSR and neighbouring countries. — Revue d'Entomologie de l'URSS 52(1): 29-38.

Curtis, J. 1838: British entomology; being illustrations and descriptions of the genera of insects found in Great Britain and Ireland: containing coloured figures of nature of the most rare, and beautiful species and in many instances of the plants upon which they are found. Privately published, London. 15: 674-721.

Dalla Torre, K. W. \& Kieffer, J. J. 1910: Das Tierreich XXIV: Cynipidae. - R. Friedlander \& Sons, Berlin. 24: 1-891.

Ferrer-Suay, M., Selfa, J. \& Pujade-Villar, J. 2011: Nuevos registros de la subfamilia Charipinae (Hymenoptera, Cynipoidea, Figitidae) para Andorra junto con una clave identificativa. - Boletín de la Asociación Española de Entomología 35(3-4): 345-367.

Ferrer-Suay, M., Paretas-Martínez, J., Selfa, J. \& PujadeVillar, J. 2012a: Taxonomic and synonymic world catalogue of the Charipinae and notes about this subfamily (Hymenoptera: Cynipoidea: Figitidae). — Zootaxa 3376: 1-92.

Ferrer-Suay, M., Selfa, J., \& Pujade-Villar J. 2012b: Revision of V.I. Belizin's type material of Alloxysta (Hymenoptera: Figitidae: Charipinae) deposited in the Zo- ological Institute of the Russian Academy of Sciences. - Zoosystematica Rossica 21(2): 279-290.

Ferrer-Suay, M., Selfa, J., \& Pujade-Villar, J. 2013a: Revision of Thomson and Zetterstedt collections of Alloxysta genus deposited in Lund Museum of Zoology (Sweden). — Entomologisk Tidskrift 134: 77-102.

Ferrer-Suay, M., Selfa, J., \& Pujade-Villar J. 2013b: Revision of Alloxysta from the Curtis collection (Hymenoptera: Figitidae: Charipinae) deposited in Museum Victoria (Australia). - Memoirs of Museum Victoria 70: $11-16$.

Hartig, T. 1840: Ueber die Familie der Gallwespen. Zeitschrift für Entomologie (Germar) 2: 176-210.

Hartig, T. 1841: Erster nachtrag zur naturgeschichte der Gallwespen. - Zeitschrift für Entomologie (Germar) 3: 322-358.

Hellén, W. 1931: Zur Kenntnis der Cynipiden-fauna Islands. - Göteborgs Kungliga Vetenskaps- och Vitterhetssamhälles Handlingar 2(5): 1-8.

Hellén, W. 1963: Die Alloxystininen Finnlands (Hymenoptera: Cynipidae). — Fauna Fennica 15: 1-23.

Kieffer, J. J. 1900: Ueber Allotrinen. — Wiener Entomologische Zeitung 19: 112-115.

Menke, A. S. \& Evenhuis, H. H. 1991: North American Charipidae: key to genera, nomenclature, species checklists, and a new species of Dilyta Förster (Hymenoptera: Cynipoidea). — Proceedings of the Entomological Society of Washington 93: 136-158.

Paretas-Martínez, J., Arnedo, M. A., Melika, G., Selfa, J., Seco-Fernández, M. V., Fülöp, D. \& Pujade-Villar, J. 2007: Phylogeny of the parasitic wasp subfamily Charipinae (Hymenoptera, Cynipoidea, Figitidae). Zoologica Scripta 36: 153-172.

Paretas-Martínez, J., Ferrer-Suay, M., Kovalev, O., Melika, G., Selfa, J. \& Pujade-Villar, J. 2011: Revision of the species of Dilyta Förster (Hymenoptera: Figitidae: Charipinae) present in the holarctic, with description of four new species from the eastern palaearctic. Zootaxa 2780: 29-38.

Pujade-Villar, J., Paretas-Martínez, J., Selfa, J., Secó-Fernández, M. V., Fülop, D. \& Melika, G. 2007: Phaenoglyphis villosa (Hartig 1841) (Hymenoptera: Figitidae: Charipinae): a complex of species or a single but very variable species? - The Annales de la Société Entomologique de France 43(2): 169-179.

Thomson, C. G. 1862: Försök till uppställning och beskrifning af Sveriges Figiter. — Öfversigt af Kongliga Vetenskaps-Akademiens förhandlingar 18: 395-420.

Thomson, C. G. 1877: Ofversikt af Sveriges Cynips-arter. — Opuscula Entomologica 8: 778-820.

Weld, L. H. 1952: Cynipoidae. 1905-1950. — Privately published. Ann Arbor, Michigan. 351 pp.

Westrum, K., Klingen, I., Hofsvang, T. \& Hågvar, E. B. 2010: Checklist of primary parasitoids and hyperparasitoids (Hymenoptera, Apocrita) on aphids (Hemiptera, Aphididae) from Norway. - Norwegian Journal of Entomology 57: 142-153.

Zetterstedt, J. W. 1838: Insecta Lapponica descripta: Hymenoptera. — Voss, Lipsiae. Pp. 315-476. 